\title{
Immunomodulator expression in trophoblasts from the feline immunodeficiency virus (FIV)- infected cat
}

Veronica L Scott ${ }^{1}$, Leslie A Shack ${ }^{2}$, Jeffrey B Eells ${ }^{2}$, Peter L Ryan ${ }^{3}$, Janet R Donaldson ${ }^{1}$ and Karen S Coats ${ }^{1,2^{*}}$

\begin{abstract}
Background: FIV infection frequently compromises pregnancy under experimental conditions and is accompanied by aberrant expression of some placental cytokines. Trophoblasts produce numerous immunomodulators that play a role in placental development and pregnancy maintenance. We hypothesized that FIV infection may cause dysregulation of trophoblast immunomodulator expression, and aberrant expression of these molecules may potentiate inflammation and compromise pregnancy. The purpose of this project was to evaluate the expression of representative pro-(TNF- $\alpha$, IFN- $\gamma$, IL-1 $\beta$, IL-2, IL-6, IL-12p35, IL-12p40, IL-18, and GM-CSF) and anti-inflammatory cytokines (IL-4, IL-5, and IL-10); CD134, a secondary co-stimulatory molecule expressed on activated T cells (FIV primary receptor); the chemokine receptor CXCR4 (FIV co-receptor); SDF-1 $\alpha$, the chemokine ligand to CXCR4; and FIV gag in trophoblasts from early-and late-term pregnancy.

Methods: We used an anti-cytokeratin antibody in immunohistochemistry to identify trophoblasts selectively, collected these cells using laser capture microdissection, and extracted total RNA from the captured cell populations. Real time, reverse transcription-PCR was used to quantify gene expression.

Results: We detected IL-4, IL-5, IL-6, IL-1 $\beta$, IL-12p35, IL-12p40, and CXCR4 in trophoblasts from early-and late-term pregnancy. Expression of cytokines increased from early to late pregnancy in normal tissues. A clear, proinflammatory microenvironment was not evident in trophoblasts from FIV-infected queens at either stage of pregnancy. Reproductive failure was accompanied by down-regulation of both pro-and anti-inflammatory cytokines. CD134 was not detected in trophoblasts, and FIV gag was detected in only one of ten trophoblast specimens collected from FIV-infected queens.

Conclusion: Feline trophoblasts express an array of pro-and anti-inflammatory immunomodulators whose expression increases from early to late pregnancy in normal tissues. Non-viable pregnancies were associated with decreased expression of immunomodulators which regulate trophoblast invasion in other species. The detection of FIV RNA in trophoblasts was rare, suggesting that the high rate of reproductive failure in FIV-infected queens was not a direct result of viral replication in trophoblasts. The influence of placental immune cells on trophoblast function and pregnancy maintenance in the FIV-infected cat requires additional study.
\end{abstract}

\section{Introduction}

Precisely-regulated placental and decidual immunomodulatory molecules such as cytokines and chemokines are necessary to establish and maintain pregnancy [1-6]. While many of the immunomodulators expressed at the maternal-fetal interface are products of decidual

\footnotetext{
* Correspondence: kcoats@grad.msstate.edu

'Department of Biological Sciences, Mississippi State University, Mississippi State, MS 39762, USA

Full list of author information is available at the end of the article
}

leukocytes such as T cells, NK cells, dendritic cells, and macrophages $[2,5,7]$, leukocytes are not exclusive producers of these molecules. Trophoblasts, including both cytotrophoblasts and syncytiotrophoblasts, are fetalderived cells of epithelial origin that form the placental chorionic villi. These cells contact and attach to the maternal endometrium and serve as a barrier between maternal and fetal blood supplies in human pregnancy [8]. Trophoblasts are a source of many cytokines and
Ciomed Central

(C) 2011 Scott et al; licensee BioMed Central Ltd. This is an Open Access article distributed under the terms of the Creative Commons Attribution License (http://creativecommons.org/licenses/by/2.0), which permits unrestricted use, distribution, and reproduction in any medium, provided the original work is properly cited. 
other immunomodulatory molecules that support both placental development and parturition [9-11].

Mother-to-child transmission of HIV remains an important source of pediatric infection worldwide [12]. The role that HIV-infected trophoblasts play in vertical transmission and pregnancy outcome is incompletely understood. In in vitro experiments using trophoblastic cell lines, cells were efficiently infected with cell associated virus [13], but not cell free virus [14] due to differences in entry pathways into the cell. In the latter case, virus production was marginally increased by treatment with TNF- $\alpha$ and IL- $1 \beta$. HIV infections can dysregulate cytokine expression in trophoblasts $[15,16]$. It has been speculated that aberrant expression of cytokines results in placental inflammation, facilitating transfer of the virus across inflamed membranes to infect the fetus [16].

Using the FIV-infected cat model for lentivirus vertical transmission, we demonstrated frequent reproductive failure in litters delivered at early-or late-gestation by cesarean section. Placental and fetal infection occurred in nearly all pregnancies in FIV-infected queens $[17,18]$. We recently reported that FIV-infection during earlyand late-term gestation affects immunomodulator expression, producing a pro-inflammatory microenvironment at early, but not late pregnancy [19]. However, the specific cell populations expressing the targeted immunomodulators were not identified. In the present study, we hypothesized that FIV infection may cause dysregulation of immunomodulator expression in trophoblasts and contribute to reproductive failure. Our objectives were to determine whether feline trophoblasts microdissected from early-and late-term placentas of infected queens were infected with FIV, to quantify trophoblast expression of representative pro-and anti-inflammatory cytokines and other immunomodulators known to be important in pregnancy, and to assess whether gene expression was related to pregnancy outcome.

\section{Methods}

\section{Animals and virus}

All procedures utilizing cats (Felis domesticus) were performed with approval of the Institutional Animal Care and Use Committee of Mississippi State University. As previously reported $[17,18]$, cats were reproductively mature, specific-pathogen-free (SPF) animals of less than 12 months of age when obtained from a commercial cattery. Ten cats were inoculated intravenously with $1 \mathrm{ml}$ of a feline plasma pool containing approximately $1.3 \times 10^{4}$ copies/ml of FIV-B-2542 (provided by Dr. Edward Hoover) [20]. Ten cats were uninoculated and served as normal controls. Infection was confirmed within 6 weeks p.i. by detection of FIV provirus by PCR and for seroconversion using the PetChek ${ }^{\circledR}$ FIV
Antibody Test Kit (IDEXX Laboratories, Inc., Westbrook, ME), then queens were allowed to breed naturally with SPF toms. Toms used to breed uninfected females were never exposed to infected females and vice versa. Breeding was observed and pregnancy was confirmed by palpation and ultrasonography.

Kittens were delivered by cesarean section during week 3 gestation (early-term)[18] and week 8 gestation (late-term) [17]. Placentas were collected under sterile conditions using the following dissection procedure. The uteri were removed and individual gestational sacs were collected. Following rinses with sterile PBS, sacs were incised with a sterile scalpel, and fetuses and placentas were collected. Placental tissues were snap frozen in liquid nitrogen and cryopreserved at $-80^{\circ} \mathrm{C}$. The effect of FIV infection on fetal viability at early-and late-term pregnancy was previously reported $[17,18]$. For this study, we evaluated placental samples from both earlyand late-term gestation, including placentas from viable and non-viable pregnancies. The placental tissues used in this study are listed in Table 1.

\section{Immunohistochemistry (IHC) to detect trophoblasts}

All IHC procedures were performed using RNase-free, sterile conditions according to established protocol using polyclonal antibody to cytokeratin to label trophoblasts [21]. To enhance the capture of trophoblasts by laser capture microdissection (LCM), sections were dehydrated in $75 \%, 95 \%$, and $100 \%$ ethanol. Sections were then placed in undiluted xylene until LCM was performed.

\section{Laser capture microdissection to capture trophoblasts}

Following immunohistochemical detection in placental specimens, trophoblasts were microdissected using the Veritas $^{\mathrm{TM}}$ Microdissection Instrument (Arcturus Bioscience, Inc., MountainView, CA). Microdissection was performed using the Capture IR laser (Power: 70

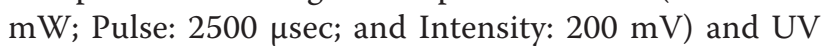
Cutting laser (Laser spot size: $\sim 8.0 \mu \mathrm{m}$ and Laser power: $7.0 \mathrm{~mW}$ ). Similar-sized fields of $\sim 2.00 \mathrm{~mm}^{2}$ were collected onto CapSure Macro LCM Caps (Arcturus). All sections and capture areas were photographed using the dissection instrument.

\section{RNA purification and quantification from microdissected tissues}

RNA was extracted from microdissected trophoblasts of FIV-B-2542-infected and uninfected queens at early gestation ( $n=5$ and $n=3$, respectively) and late gestation ( $\mathrm{n}=5$ and $\mathrm{n}=3$, respectively), using the PicoPure RNA Isolation Kit (Arcturus). All RNA samples were treated with DNase to remove contaminating genomic DNA. RNA was quantified using the NanoDrop ${ }^{\mathrm{TM}} 3300$ 
Table 1 Placental Tissue Evaluated in Study

\begin{tabular}{|c|c|c|c|c|c|c|}
\hline $\begin{array}{l}\text { Queen number and } \\
\text { placenta }\end{array}$ & $\begin{array}{l}\text { Pregnancy } \\
\text { term }\end{array}$ & $\begin{array}{l}\text { Queen FIV } \\
\text { status }\end{array}$ & Fetal viability & $\begin{array}{c}\text { Fetus FIV } \\
\text { Status } \\
{[17,27]}\end{array}$ & $\begin{array}{c}\text { Placenta FIV status } \\
{[17,27]}\end{array}$ & $\begin{array}{c}\text { Trophoblast } \\
\text { FIV } \\
\text { Status/Ct } \\
\text { value } \\
\end{array}$ \\
\hline 2779 Placenta B & Early & - & Viable & NT & NT & - \\
\hline 2779 Placenta D & Early & - & Viable & NT & NT & - \\
\hline 2779 Placenta E & Early & - & $\begin{array}{l}\text { Non-viable; } \\
\text { resorption }\end{array}$ & NT & NT & - \\
\hline 0326 Placenta A & Early & + & Viable & + & + & - \\
\hline 8035 Placenta B & Early & + & Non-viable; arrested & - & + & - \\
\hline 8035 Placenta C & Early & + & Non-viable; arrested & + & + & - \\
\hline 0866 Placenta A & Early & + & Viable & + & + & - \\
\hline 0866 Placenta B & Early & + & $\begin{array}{l}\text { Non-viable; } \\
\text { resorption }\end{array}$ & + & + & - \\
\hline 9581 Placenta A & Late & - & Viable & NT & NT & - \\
\hline 9581 Placenta B & Late & - & Viable & NT & NT & - \\
\hline 9746 Placenta C & Late & - & Viable & NT & NT & - \\
\hline 9730 Placenta B & Late & + & Viable & + & + & - \\
\hline 9730 Placenta R1 & Late & + & $\begin{array}{l}\text { Non-viable; } \\
\text { resorption }\end{array}$ & - & NT & - \\
\hline 9730 Placenta R3 & Late & + & $\begin{array}{l}\text { Non-viable; } \\
\text { resorption }\end{array}$ & - & + & $+/>37$ \\
\hline 13226 Placenta C & Late & + & Non-viable; arrested & + & + & - \\
\hline 13226 Placenta D & Late & + & Non-viable; arrested & + & + & - \\
\hline
\end{tabular}

$\mathrm{NT}=$ not tested

Fluorospectrometer (Thermo Fisher Scientific, Inc. Waltham, MA). All RNA was stored at $-80^{\circ} \mathrm{C}$ until used.

\section{Reverse transcription-PCR to generate CDNA}

Using the following cycling program: $25^{\circ} \mathrm{C}, 10 \mathrm{~min} ; 37^{\circ} \mathrm{C}$, $120 \mathrm{~min} ; 85^{\circ} \mathrm{C}$, $5 \mathrm{sec} ; 4^{\circ} \mathrm{C}$, hold, cDNA was synthesized using the High Capacity cDNA Reverse Transcription Kit (Applied Biosystems, Inc., Foster City, CA) according to the manufacturer's instructions. Briefly, each reverse transcription reaction was performed in a final reaction volume of $20 \mu \mathrm{l}$ containing $2 \mu \mathrm{l}$ of the 10X RT buffer, 2 $\mu \mathrm{l}$ R random primers, $0.8 \mu \mathrm{l}$ of $25 \mathrm{X} \mathrm{dNTP}, 1 \mu \mathrm{l}$ of Multiscribe Reverse Transcriptase, $1 \mu$ l RNase inhibitor, 3.2 $\mu \mathrm{l}$ of RNase-free water, and $10 \mu \mathrm{l}$ of $30-800 \mathrm{pg}$ RNA template. All cDNA was stored at $-20^{\circ} \mathrm{C}$ until used.

\section{Primer design of feline immunomodulators and internal control}

The immunomodulators evaluated were representative pro-(TNF- $\beta$, IFN- $\gamma$, IL- $1 \beta$, IL- 2 , IL-6, IL-12p35, IL12p40, IL-18, and GM-CSF) and anti-inflammatory (IL-4, IL-5, and IL-10) cytokines; CD134, a secondary co-stimulatory molecule expressed on activated $\mathrm{T}$ cells (FIV primary receptor); CXCR4, a chemokine receptor (FIV co-receptor); and SDF-1 $\alpha$, the chemokine ligand to CXCR4. All the immunomodulators were known to be expressed in placental/decidual tissues and important to the establishment and maintenance of pregnancy.
Sequences of PCR primers and TaqMan probes specific for feline immunomodulators and the housekeeping gene $\beta$-actin were either designed as previously reported $[19,22]$ or obtained from the literature [17,23-26]. The primer/probe sequences are listed in Table 2.

\section{Evaluation of expression of immunomodulators using TaqMan real-time PCR}

The real-time PCR (qPCR) used an iCycler (Bio-Rad) and the following cycling program: $50^{\circ} \mathrm{C}, 2 \mathrm{~min} ; 95^{\circ} \mathrm{C}, 10 \mathrm{~min}$; $60 \mathrm{X}\left(95^{\circ} \mathrm{C}, 15 \mathrm{~s} ; 60^{\circ} \mathrm{C}, 1 \mathrm{~min}\right)$. Each reaction contained 10 $\mu \mathrm{l}$ of the $2 \mathrm{X}$ TaqMan ${ }^{\circledR}$ Universal PCR Master Mix (Applied Biosystems, Life Technologies Corp., Carlsbad, CA), $1 \mu \mathrm{l}$ of forward and reverse primers $(10 \mathrm{pmol} / \mu \mathrm{l}), 1$ $\mu \mathrm{l}$ of the respective probe $(100 \mathrm{fmol} / \mu \mathrm{l})$, and $\sim 2-4 \mu \mathrm{g}$ cDNA. For every placental cDNA sample, parallel reactions were performed in triplicate simplex reactions on separate plates for each gene. Due to the low concentration of RNA isolated from extracted cells, and consequently, the limited amount of cDNA available for use in qPCR, standard curves for internal control and target gene amplicons were generated using pooled, serially-diluted whole placental tissue RNA from representative uninfected cats. Each titration simplex reaction contained 6.25 $\mu \mathrm{l}$ of the $2 \mathrm{X}$ Thermoscript $\mathrm{t}^{\mathrm{TM}}$ reaction mix, $0.25 \mu \mathrm{l}$ of Thermoscript $^{\mathrm{TM}} \mathrm{RT} /$ Platinum $^{\circledR}$ Taq Mix (Invitrogen), $1 \mu \mathrm{l}$ of forward and reverse primers $(10 \mathrm{pmol} / \mu \mathrm{l}), 1 \mu \mathrm{l}$ of the respective probe $(100 \mathrm{fmol} / \mu \mathrm{l})$, and five-fold diluted $2 \mu \mathrm{g}$ 
Table 2 Primers and Probes used to Evaluate Immunomodulator and Virus Expression

\begin{tabular}{|c|c|c|c|c|c|}
\hline Gene & Primer & $\begin{array}{l}\text { Primer Sequence } \\
\left(5^{\prime} \text { to } 3^{\prime}\right)\end{array}$ & $\begin{array}{l}\text { Primer } \\
\text { Length }\end{array}$ & Probe Sequence $\left(5^{\prime}\right.$ to $\left.3^{\prime}\right)$ & $\begin{array}{l}\text { Accession \# or } \\
\text { Reference }\end{array}$ \\
\hline \multirow[t]{2}{*}{$\beta$ actin } & Forward & GACTACCTCATGAAGATCCTCACG & 24 & ACAGTTCACCACCACCGCCGAGC & AB051104 \\
\hline & Reverse & CCTTGATGTCACGCACAATTTCC & 23 & & \\
\hline \multirow[t]{2}{*}{ IL-1 $1 \beta$} & Forward & ATTGTGGCTATGGAGAAACTGAAG & 24 & TTTGCCTGCTCACAACCCCTCCAG & M92060 \\
\hline & Reverse & TCTTCTTCAAAGATGCAGCAAAAG & 24 & & \\
\hline \multirow[t]{2}{*}{ |L-6 } & Forward & GTGTGACAACTATAACAAATGTGAGG & 26 & CAAGGAGGCACTGGCAGAAAACAACCT & L16914 \\
\hline & Reverse & GTCTCCTGATTGAACCCAGATTG & 23 & & \\
\hline \multirow[t]{2}{*}{ IL-10 } & Forward & ACTTCTTCAAACCAAGGACGAG & 24 & TCTCGGACAAGGCTTGGCAACCCA & AF060520 \\
\hline & Reverse & GGCATCACCTCCTCCAAATAAAAC & 24 & & \\
\hline \multirow{2}{*}{$\begin{array}{l}\text { IL- } \\
12 p 35\end{array}$} & Forward & ACACCAAGCCCAGGAATGTTC & 21 & AACCACTCCCAAACCCTGCTGCGA & U83185 \\
\hline & Reverse & TGGCCTTCTGAAGCGTGTTG & 20 & & \\
\hline \multirow{2}{*}{$\begin{array}{l}\text { IL- } \\
12 \mathrm{p} 40\end{array}$} & Forward & GAAGTACACAGTGGAGTGTCAGG & 23 & CAGTGCCTGCCCGGCTGCCG & U83184 \\
\hline & Reverse & GGTTGATGATGTCCCTGATGAAG & 24 & & \\
\hline \multirow[t]{2}{*}{ CD134 } & Forward & CAGGTTATGGGATGGAGAGTCG & 22 & TGACCAGGACACCAAGTGCCTCCAGTG & AY738589 \\
\hline & Reverse & TGCAAGGCTCGTAGTTCACG & 20 & & \\
\hline \multirow[t]{2}{*}{ CXCR4 } & Forward & AAGGCAGTCCATGTCATCTACAC & 23 & ACCTCTACAGCAGTGTCCTCATCCTGGC & AJ009816 \\
\hline & Reverse & AGACCACCTTTTCAGCCAACAG & 22 & & \\
\hline \multirow[t]{2}{*}{ SDF-1 $1 \alpha$} & Forward & GCTACAGATGTCCTTGCCGATTC & 23 & TCGAGAGCCACGTTGCCAGAGCCA & AB011965 \\
\hline & Reverse & TCTTCAGCCTCGCCACGATC & 20 & & \\
\hline \multirow[t]{2}{*}{$\mid \mathrm{L}-2$} & Forward & ACGGTTGCTTTTGAATGGAG & 20 & CCCCAAACTCTCCAGGATGCTCA & Ref 23 \\
\hline & Reverse & CAATTCTGTGGCCTTCTTGG & 20 & & \\
\hline \multirow[t]{2}{*}{$\mid \mathrm{L}-4$} & Forward & CCCCTAAGAACACAAGTGACAAG & 23 & TTCTGCAGAGCCACAACCGTGC & Ref 23 \\
\hline & Reverse & CCTTTGAGGAATTGGTGGAG & 21 & & \\
\hline \multirow[t]{2}{*}{ IL-5 } & Forward & TGCTTCTGCATTTGAGTTTG & 20 & TGGCAGAAACATAGGCAGCCCC & Ref 23 \\
\hline & Reverse & CAGCCTATTCATGGGACTTTG & 21 & & \\
\hline \multirow[t]{2}{*}{ IL-18 } & Forward & GGAGATCAACCTGTGTTTGAGGAT & 24 & ATTCTGACTGTACAGATAATGCACCCCGGAC & Ref 25 \\
\hline & Reverse & GATGGTTACTGCCAGACCTCTAGTG & 25 & & \\
\hline \multirow[t]{2}{*}{ GM-CSF } & Forward & AATGAAACGGTAGAAGTCGTCTCTG & 25 & TTGACCCTGAGGAGCCGAATTGCC & Ref 26 \\
\hline & Reverse & CGTACAGCTTTAGGTGAGTCTGCA & 24 & & \\
\hline \multirow[t]{2}{*}{ IFN- $\gamma$} & Forward & TGGTGGGTCGCTITCGTAG & 20 & CATTTTGAAGAACTGGAAAGAGGAGAGTGATAAAACAAT & Ref 24 \\
\hline & Reverse & GAAGGAGACAATTTGGCTTTGAA & 23 & & \\
\hline \multirow[t]{2}{*}{ TNF- $\alpha$} & Forward & CTTCTCGAACTCCGAGTGACAAG & 23 & TAGCCCATGTAGTAGCAAACCCCGAAGC & Ref 26 \\
\hline & Reverse & CCACTGGAGTTGCCCTTCA & 19 & & \\
\hline \multirow[t]{2}{*}{ GAG } & Forward & GTATGATCGTACTCATCCTCCTGAT & 25 & AGACCACTGCCCTACTTCACTGCCG & Ref 17 \\
\hline & Reverse & TCTACATTGCATTCTGGCTGGT & 22 & & \\
\hline
\end{tabular}

RNA as starting titration template. The standard curves were used to normalize for differences in PCR efficiency between the internal control and target genes and between sample plate runs. Differences in the amount of template cDNA in each reaction was corrected by the cycle threshold $(\mathrm{Ct})$ value for $\beta$-actin. Normalized samples were divided by the calibration, generating the relative expression levels.

\section{Statistical analysis}

Statistical evaluation of fetal viability from early-and lateterm gestation was previously reported $[17,18]$. Statistical analyses of immunomodulator expression for early-and late-term control and FIV-B-2542-infected trophoblasts were done using single-factor ANOVA and the two independent sample Wilcoxon rank sum test (SOCR Analysis, University of California, Los Angeles, CA).

\section{Result}

Microdissection of trophoblasts from placental tissues

Figure 1 shows a representative placental specimen following immunolabeling with anti-cytokeratin antibody and laser capture microdissection of trophoblasts. Cytokeratin labeling was specific for trophoblasts [21].

\section{Expression of FIV gag in trophoblasts}

FIV gag was detected in only a single, late-term trophoblast specimen, collected from a placenta associated 


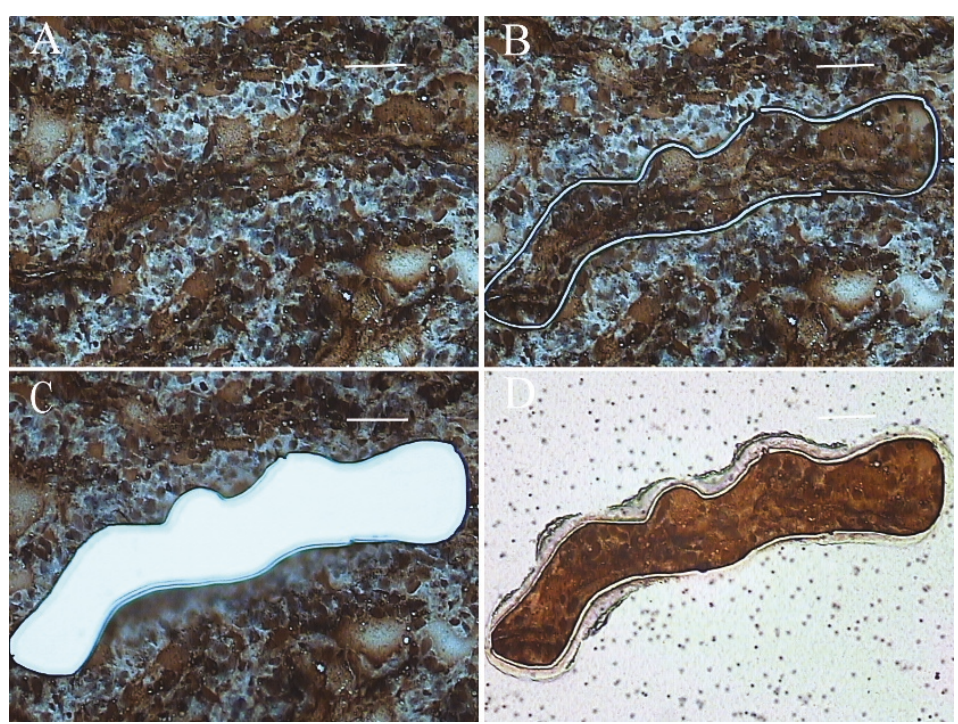

Figure 1 Laser Capture Microdissection of IHC-stained Trophoblasts from a Representative FIV-negative Cat. Trophoblasts were labeled using antibody to cytokeratin, and cytokeratin-positive trophoblasts were evident by brown staining. (A) Trophoblasts were selectively identified. (B) Areas of trophoblast-rich populations were cut and captured using the UV cutting laser and Capture IR laser, respectively. (C) Selected trophoblasts were removed from the tissue. (D) Trophoblasts were attached to the cap. All photography was performed with the 20X objective. Bars $=200$ microns.

with a fetal resorption (Table 1). The high Ct value (greater than 37) indicated low level infection of this trophoblast specimen. FIV gag was previously detected in RNA from whole placental tissues using the same protocol [27].

\section{Expression of immunomodulators in trophoblasts}

Messenger RNA for IL-4, IL-5, IL-6, IL-1 $\beta$, IL-12p35, IL-12p40, and CXCR4 was expressed in all early-and late-term trophoblasts. Messenger RNA for TNF- $\alpha$, IFN- $\gamma$, IL-2, IL-18, IL-10, GM-CSF, CD134, and SDF-1 $\alpha$ was not detected in trophoblasts from either stage of pregnancy. All immunomodulators were amplified from RNA extracted from whole placental tissues used for generating standard curves (data not shown), indicating that failure to detect some of them in trophoblasts was not a result of inadequate qPCR conditions.

To determine normal feline trophoblast expression of the detected immunomodulators between the two stages of pregnancy, data obtained from control placentas from early-and late-term were compared. Trophoblasts from control cats at late gestation expressed more IL-4, IL-6, IL-1 $\beta$, IL-12p35, IL-12p40, and CXCR4 mRNA than trophoblasts from control cats at early gestation $(\mathrm{p}<0.05)$. Only IL-5 did not differ between the two stages of pregnancy $(\mathrm{p}=0.135)$ (Figure $2 \mathrm{~A})$.

To determine the effect of FIV infection on expression of these immunomodulators, trophoblasts from FIV-infected and control queens at both early-and late-term gestation were compared. At early gestation, the marginally-reduced expression of nearly all immunomodulators in FIV-infected cats did not reach the level of significance. The expression of the anti-inflammatory cytokine IL- 5 alone was decreased to a significant level $(\mathrm{p}=0.038)$ (Figure $2 \mathrm{~B})$. At late gestation, FIV-infection resulted in decreased expression of the anti-inflammatory cytokine IL-4 $(\mathrm{p}=0.021)$ and the proinflammatory cytokine IL-12p35 ( $\mathrm{p}=0.021)$; decreased expression of the pro-inflammatory cytokine IL-12p40 $(\mathrm{p}=$ 0.057 ) approached, but did not reach significance. There was no significant effect on the expression of the remaining immunomodulators (Figure 2C).

To determine whether cytokine expression was related to fetal viability regardless of infection, trophoblasts from all viable pregnancies were compared to trophoblasts from all non-viable pregnancies for both early-and late-term gestation (Figure 3). At early gestation, trophoblasts from non-viable pregnancies expressed significantly less IL-4 ( $\mathrm{p}=0.032), \mathrm{IL}-6(\mathrm{p}=0.048), \mathrm{IL}-12 \mathrm{p} 35$ $(\mathrm{p}=0.001)$, and CXCR4 $(\mathrm{p}=0.004)$ mRNA than those of viable pregnancies (Figure $3 \mathrm{~A}$ ). The decreased IL- $1 \beta$ expression in non-viable pregnancies approached, but did not reach the level of significance $(p=0.052)$. At late gestation, trophoblasts from non-viable pregnancies expressed significantly less IL-4 ( $\mathrm{p}=0.021), \mathrm{IL}-12 \mathrm{p} 35$ ( $\mathrm{p}$ $=0.021)$, and IL-12p40 $(\mathrm{p}=0.038)$ than trophoblasts from viable pregnancies (Figure 3B).

\section{Discussion}

Using the FIV-infected, pregnant cat to evaluate lentivirus-induced placental immunopathology and 

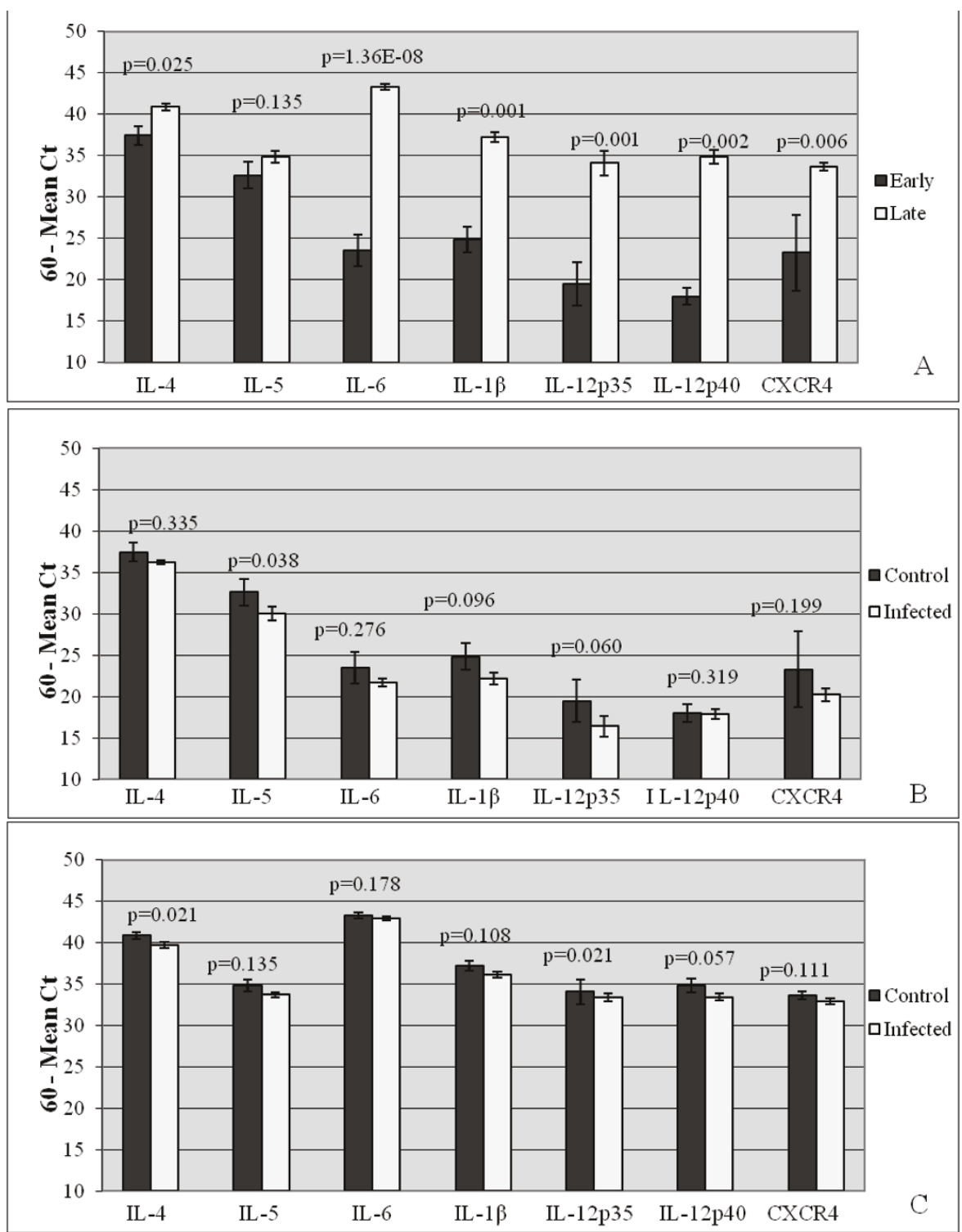

Figure 2 Relative Expression of Immunomodulators in Trophoblasts from Early-and Late-Term Feline Placentas. Real-time RT-PCR analysis of feline placental trophoblast expression of the pro-inflammatory cytokines (IL-6, IL-1 $\beta$, IL-12p35, and IL-12p40), the anti-inflammatory cytokines (IL-4 and IL-5), and the chemokine receptor (CXCR4) in: (A) early-term uninfected placentas $(n=3)$ versus late-term uninfected placentas ( $n=3)$; (B) early-term FIV-infected $(n=5)$ versus uninfected placentas; (C) late-term FIV-infected $(n=5)$ versus uninfected placentas. Bars represent mean Ct values substracted from a negative endpoint (60-mean Ct), bracketed by standard errors of the mean. $P$ values obtained from single factor ANOVA and Wilcoxon rank sum test are noted. $P$ values $\leq 0.05$ were considered significant.

pregnancy outcome, we and others reported vertical transfer of FIV-B-2542 at early-and late-term pregnancy $[17,18,28]$, with more than $50 \%$ of offspring infected. We found fetal non-viability to be significantly higher in FIV-infected queens at both stages of pregnancy $[17,18]$. While the mechanism of FIV-induced reproductive failure is unresolved, placental inflammation appears to accompany FIV infection, especially at early pregnancy. In a previous report by our laboratory which evaluated immunomodulator expression in whole placental specimens [19], an FIV-induced, pro-inflammatory microenvironment at early, but not late pregnancy, was evident, including increased expression of IL- 6 and IL12 , decreased expression of IL-10, and IL-12:IL-10 ratios that favored the pro-inflammatory cytokine in infected cats at early pregnancy.

In the present study, the effect of FIV infection on immunomodulator expression in a targeted cell population, trophoblasts, was evaluated at early and late gestation. Immunomodulators produced by trophoblasts play 


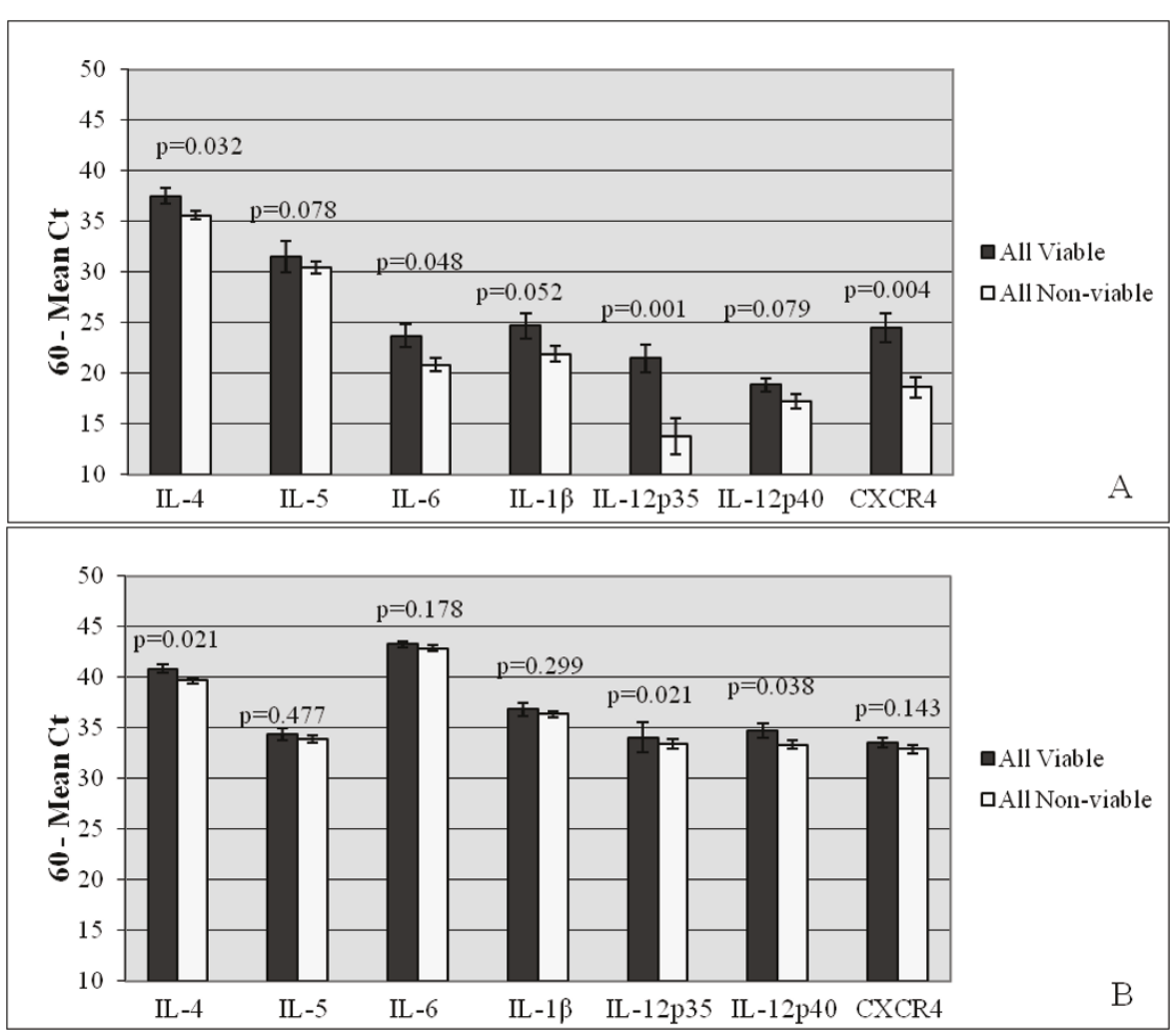

Figure 3 Relative Expression of Immunomodulators in Trophoblasts from Early-and Late-Term Feline Placentas from Viable and Nonviable Pregnancies. Real-time RT-PCR analysis of trophoblast expression of the pro-inflammatory cytokines (IL-6, IL-1 1 , IL-12p35, and IL-12p40), the anti-inflammatory cytokines (IL-4 and IL-5), and the chemokine receptor (CXCR4) in early-(A) and late-term (B) placentas from all viable $(n=4$ each for early and late tissues) versus all non-viable ( $n=4$ each for early and late tissues) pregnancies. Bars represent mean $C t$ values substracted from a negative endpoint (60-mean Ct), bracketed by standard errors of the mean. P values obtained from Wilcoxon rank sum test are noted. $P$ values $\leq 0.05$ were considered significant.

important roles in the progression of pregnancy. Thus, understanding how infections or perturbed pregnancy correspond to altered gene expression specifically in trophoblasts, in situ and in vitro, has been the focus of many investigations [29-32]. We were able to detect expression of IL-4, IL-5, IL-6, IL-1 $\beta$, IL-12p35, IL$12 \mathrm{p} 40$, and CXCR4 in feline placental trophoblasts at both time points during feline gestation. The relative expression of all immunomodulators increased in normal specimens as gestation progressed, indicating increased immunomodulatory function of feline trophoblasts at late pregnancy. At early gestation, FIV infection was associated with slightly decreased expression of all cytokines, although only the expression of IL-5 (an antiinflammatory cytokine) decreased to significant levels. At late gestation one anti-inflammatory cytokine (IL-4) and one pro-inflammatory cytokine (IL-12p35) were decreased in FIV-infected queens. The data suggest that FIV infection of the queens caused a minor effect on trophoblast function, and an FIV-induced pro-inflammatory effect in trophoblasts was not clearly evident.
Non-viable pregnancies were accompanied by decreased trophoblast expression of both pro-and antiinflammatory immunomodulators at early-(IL-4, IL-6, IL-12p35, and CXCR4) and late-term (IL-4, IL-12p35, and IL-12p40). One would predict reduced placental function in dying pregnancies. However, decreased gene expression was not significant for all immunomodulators, suggesting that reduction in immunomodulator function was not solely attributable to deterioriation of the placenta in non-viable pregnancies. The decreased expression of IL-4 and IL-6 in early placental trophoblasts from non-viable pregnancies parallels the IL-4 and IL- 6 expression patterns found in the endometrial tissue and deciduas of women with frequent implantation failures[33] and recurrent abortions [34]. IL-4 is a Th2 cytokine that is mainly involved in the peri-implantation period of placental development [35]. Along with transforming growth factor $-\beta$ (TGF- $\beta$ ), IL- 4 mediates the process of trophoblast invasion during human placentation [36-39]. IL-4 and IL-6 contribute to the angiogenesis of trophoblastic villi [40]. Silencing of IL-6 in 
JEG-3 cells (choriocarcinoma cells maintaining trophoblast-like characteristics) using siRNA resulted in significantly reduced proliferation of those cells [41]. IL-1 $\beta$ activates matrix metalloprotease 3 (MMP-3), a protease that digests extracellular matrix proteins and allows trophoblast penetration of the maternal endometrium [42]. In the present study, the decrease in expression of IL-1 $\beta$ approached significance $(\mathrm{p}=0.052)$ at early pregnancy. In the human placenta, CXCR4, expressed by trophoblasts, is also important in trophoblast invasion via interaction with its ligand, SDF-1 $\alpha$, expressed on decidual stromal cells [43]. In addition, this interaction protects trophoblasts from apoptosis via stimulation of anti-apoptotic pathways [44]. IL-12, a heterodimeric cytokine consisting of 35 and $40 \mathrm{kd}$ protein subunits, is also an important regulator of trophoblast invasion. It inhibits trophoblast invasion by causing an IFN- $\gamma$-dependent reduction in expression of MMP-2, MMP-9, urokinase-type plasminogen activator, and other proteases that digest extracellular matrix proteins. IL-12 also causes an increase in expression of inhibitors of these proteases [45]. The decreased expression of IL-4, IL-6, IL-12p35, and CXCR4 in trophoblasts from early-term non-viable pregnancies shows dysregulation of putative mediators of feline trophoblast invasion during early feline gestation, an outcome that could result in nutrient and oxygen deprivation of the developing fetus and account for the increased reproductive failure that occurred in infected animals.

In contrast, cultured placental trophoblasts from HIVinfected women expressed significantly higher amounts of IL-1 $\beta$, IL- 6 , and TNF- $\alpha$ than placentas from uninfected women [16]. These data indicate that HIV-infection during pregnancy results in increased cytokine expression and that a pro-inflammatory microenvironment (an environment potentially conducive to vertical transfer) exists in HIV-infected placentas. We did not see this trend in trophoblasts collected from the cat model. However, the study of human tissues used cultured trophoblasts, whereas in the present study, RNA was extracted from trophoblasts microdissected from frozen placentas. Whether culturing the cells affected gene expression is unknown.

While we previously reported the detection of mRNA for the primary FIV receptor CD134 in whole feline placental tissues [46], we did not detect CD134 in any trophoblast sample from early-or late-term pregnancy. Correspondingly, FIV was detectable at a low level $(\mathrm{Ct}>$ 37) in only one trophoblast specimen, a placenta from a late-term fetal resorption, indicating that trophoblasts may not be highly susceptible or permissive to FIV infection. This result was surprising, given the high frequency of fetal infection that was documented in these same cats $[17,18]$, and suggests that infected trophoblasts may not be the source of fetal infection. We speculate that immune cells in the surrounding microenvironment, such as regulatory $\mathrm{T}$ cells (Tregs) or Th17 cells, the former of which are known to support the replication of FIV $[47,48]$, may influence trophoblast function and serve as the source of fetal infection. Our laboratory is currently investigating feline Tregs and Th17 cells in lentivirus-induced placental immunopathology and pregnancy failure.

A limitation of this study was the small number of tissues evaluated by LCM, particularly in terms of separating viable versus non-viable tissues. LCM is a procedure which is laborious, time-intensive, and expensive to perform, so limiting the samples collected was a necessity. We attempted to minimize inter-cat variability by evaluating multiple placentas from the same queen where possible. The differences that we have historically observed between placentas from the same queen assured us that we can consider placentas from the same queens as independent specimens [17,19,27]. Yet, the inclusion of additional placental specimens may have strengthened the statistical power and allowed us to identify additional viral effects. In addition, it is impossible to eliminate all cell contamination from the microenvironment surrounding the trophoblasts due to limitations in the precision of focusing the laser. However, our samples were highly enriched for trophoblasts, as is evident by the well-defined tissue lifts that we were able to achieve (Figure 1). LCM followed by qPCR has been used as a means to collect trophoblasts from whole placental specimens and measure gene expression in these cells by others [49]. Regardless of the limitations, this study provides novel information. Our previous reports clearly reveal that FIV infection results in significantly higher rates of reproductive failure, probably by inducing placental immunopathology [17-19]. The present data shed additional light on this anomaly, suggesting that aberrant expression of trophoblast cytokines that may regulate trophoblast invasion accompanies fetal demise.

\section{Conclusion}

Feline trophoblasts expressed an array of pro-and antiinflammatory immunomodulators whose expression increased from early to late pregnancy in normal tissues, while some immunomodulators that were expressed in whole placental tissues were not detected. A virusinduced, pro-inflammatory environment was not detected in trophoblasts. Non-viable pregnancies were associated with decreased expression of immunomodulators which regulate trophoblast invasion in other species, a finding which may explain the high rate of reproductive failure in FIV-infected cats. The detection of FIV RNA in trophoblasts was rare. This result 
suggests that reproductive failure and altered trophoblast gene expression in FIV-infected queens was not a direct result of viral infection of trophoblasts, but perhaps was influenced by cells in the microenvironment adjacent to trophoblasts. The effects of placental immune cells on trophoblast function and pregnancy maintenance in the FIV-infected cat requires additional study.

\section{Acknowledgements}

We thank Dr. Shane C. Burgess, College of Veterinary Medicine, Mississippi State University, for the use of laboratory facilities and advice in quantitative PCR. We are grateful to Dr. Edward A. Hoover, Colorado State University, for providing the FIV-B-2542 inoculum. We thank Aimee Bell for assistance with LCM and the veterinary staff at the College of Veterinary Medicine,

Mississippi State University for assistance with surgeries and animal care. This project was supported by the National Institutes of Health (2R15AI04841902A1) and (3R15AI048419-02A1S1).

\section{Author details}

'Department of Biological Sciences, Mississippi State University, Mississippi State, MS 39762, USA. ${ }^{2}$ Department of Basic Sciences, College of Veterinary Medicine, Mississippi State University, Mississippi State, MS 39762, USA. ${ }^{3}$ Department of Pathobiology and Population Medicine, Mississippi State University, Mississippi State, MS 39762, USA.

\section{Authors' contributions}

VLS conducted all aspects of the research and data analysis and wrote drafts of the manuscript. LAS provided technical assistance with qPCR. JBE, PLR, and JRD served as consultants and provided important advice relative to LCM, trophoblast IHC, and CDNA synthesis, respectively. KSC secured funding, directed the research, contributed to data analysis, and finalized the manuscript. All authors read and approved the manuscript.

\section{Competing interests}

The authors declare that they have no competing interests.

Received: 24 June 2011 Accepted: 5 July 2011 Published: 5 July 2011

\section{References}

1. Bennett WA, Lagoo-Deenadayalan S, Stopple JA, Barber WH, Hale E, Brackin MN, Cowan BD: Cytokine expression by first-trimester human chorionic villi. Am J Reprod Immunol 1998, 40:309-318.

2. Challis JR, Lockwood CJ, Myatt L, Norman JE, Strauss JF, Petraglia F: Inflammation and pregnancy. Reprod Sci 2009, 16:206-215.

3. Robertson SA, Seamark RF, Guilbert L, Wegmann TG: The role of cytokines in gestation. Crit Rev Immunol 1994, 14:239-292.

4. Saito S: Cytokine cross-talk between mother and the embryo/placenta. J Reprod Immunol 2001, 52:15-33.

5. Munoz-Suano A, Hamilton AB, Betz AG: Gimme shelter: the immune system during pregnancy. Immunological Reviews 2011, 241:20-38.

6. TokmadŻIC VS, Tsuji Y, BogoviĆ T, LaŠKarin G, Cupurdija K, Š Trbo N, Koyama K, Okamura H, Podack ER, Rukavina D: IL-18 is Present at the Maternal-Fetal Interface and Enhances Cytotoxic Activity of Decidual Lymphocytes. American Journal of Reproductive Immunology 2002, 48:191-200.

7. Beer AE, Kwak JYH: Immunology of normal pregnancy. Immunol Allergy Clin N Am 1998, 18:249-270.

8. Senger PL: Chapter 14. Placentation, Gestation, and Parturition. Pathways to Pregnancy and Parturition. 1 edition. Pullman, WA: Current Conceptions, Inc; 1997, 233-247.

9. Hauguel-de Mouzon S, Guerre-Millo M: The placenta cytokine network and inflammatory signals. Placenta 2006, 27:794-798.

10. Weetman AP: The immunology of pregnancy. Thyroid 1999, 9:643-646.

11. Bowen JM, Chamley L, Keelan JA, Mitchell MD: Cytokines of the Placenta and Extra-placental Membranes: Roles and Regulation During Human Pregnancy and Parturition. Placenta 2002, 23:257-273.
12. Key facts by region-2008 Report on the global AIDS epidemic. [http:// data.unaids.org/pub/GlobalReport/2008/20080715_fs_regions_en.pdf].

13. Lagaye S, Derrien M, Menu E, Coito C, Tresoldi E, Mauclere P, Scarlatti G, Chaouat G, Barre-Sinoussi F, Bomsel M: Cell-to-cell contact results in a selective translocation of maternal human immunodeficiency virus type 1 quasispecies across a trophoblastic barrier by both transcytosis and infection. J Virol 2001, 75:4780-4791.

14. Vidricaire G, Tardif MR, Tremblay MJ: The low viral production in trophoblastic cells is due to a high endocytic internalization of the human immunodeficiency virus type 1 and can be overcome by the pro-inflammatory cytokines tumor necrosis factor-alpha and interleukin1. J Biol Chem 2003, 278:15832-15841.

15. Lee BN, Ordonez N, Popek EJ, Lu JG, Helfgott A, Eriksen N, Hammill H, Kozinetz C, Doyle M, Kline M, et al: Inflammatory cytokine expression is correlated with the level of human immunodeficiency virus (HIV) transcripts in HIV-infected placental trophoblastic cells. J Virol 1997, 71:3628-3635.

16. Shearer WT, Reuben J, Lee BN, Popek EJ, Lewis DE, Hammill HH, Hanson IC, Kline MW, Langston C: Role of placental cytokines and inflammation in vertical transmission of HIV infection. Acta Paediatr Suppl 1997, 421:33-38.

17. Weaver CC, Burgess SC, Nelson PD, Wilkinson M, Ryan PL, Nail CA, KellyQuagliana KA, May ML, Reeves RK, Boyle CR, Coats KS: Placental immunopathology and pregnancy failure in the FIV-infected cat. Placenta 2005, 26:138-147.

18. Boudreaux CE, Lockett NN, Chemerys DN, Clay BT, Scott VL, Willeford B, Brown T, Coats KS: Maternal hematological and virological characteristics during early feline immunodeficiency virus (FIV) infection of cats as predictors of fetal infection and reproductive outcome at early gestation. Vet Immunol Immunopathol 2009, 131:290-297.

19. Scott VL, Boudreaux CE, Lockett NN, Clay BT, Coats KS: Cytokine Dysregulation in Early-and Late-Term Placentas from Feline Immunodeficiency Virus (FIV)-Infected Cats. American Journal of Reproductive Immunology 2011, 65:480-491.

20. Rogers $A B$, Hoover $E A$ : Maternal-fetal feline immunodeficiency virus transmission: timing and tissue tropisms. J Infect Dis 1998, 178:960-967.

21. Scott VL, Wallace K, Mays S, Ryan P, Coats KS: An immunohistochemical assay to detect trophoblasts in frozen feline placenta. J Vet Diagn Invest 2011, 23:275-281.

22. Scott VL, Burgess SC, Shack LA, Lockett NN, Coats KS: Expression of CD134 and CXCR4 mRNA in term placentas from FIV-infected and control cats. Vet Immunol Immunopathol 2008, 123:90-96.

23. Taglinger K, Van Nguyen N, Helps CR, Day MJ, Foster AP: Quantitative realtime RT-PCR measurement of cytokine mRNA expression in the skin of normal cats and cats with allergic skin disease. Veterinary Immunology and Immunopathology 2008, 122:216-230.

24. Leutenegger CM, Mislin CN, Sigrist B, Ehrengruber MU, HofmannLehmann R, Lutz H: Quantitative real-time PCR for the measurement of feline cytokine mRNA. Veterinary Immunology and Immunopathology 1999, 71:291-305.

25. Foley JE, Rand C, Leutenegger C: Inflammation and changes in cytokine levels in neurological feline infectious peritonitis. J Feline Med Surg 2003, 5:313-322.

26. Kipar A, Meli ML, Failing K, Euler T, Gomes-Keller MA, Schwartz D, Lutz H, Reinacher M: Natural feline coronavirus infection: differences in cytokine patterns in association with the outcome of infection. Vet Immunol Immunopathol 2006, 112:141-155.

27. Lockett NN, Scott VL, Boudreaux CE, Clay BT, Pruett SB, Ryan PL, Coats KS: Expression of regulatory $\mathrm{T}$ cell (Treg) activation markers in endometrial tissues from early and late pregnancy in the feline immunodeficiency virus (FIV)-infected cat. Placenta 2010, 31:796-802.

28. O'Neil LL, Burkhard MJ, Hoover EA: Frequent perinatal transmission of feline immunodeficiency virus by chronically infected cats. J Virol 1996, 70:2894-2901.

29. Burrough ER, DiVerde KD, Sahin O, Plummer PJ, Zhang Q, Yaeger MJ: Expression of Toll-like Receptors 2 and 4 in Subplacental Trophoblasts From Guinea Pigs (Cavia porcellus) Following Infection With Campylobacter jejuni. Veterinary Pathology Online 2011, 48:381-388.

30. Riewe SD, Mans JJ, Hirano T, Katz J, Shiverick KT, Brown TA, Lamont RJ: Human trophoblast responses to Porphyromonas gingivalis infection. Molecular Oral Microbiology 2010, 25:252-259. 
31. Aldo PB, Mulla MJ, Romero R, Mor G, Abrahams VM: Viral ssRNA Induces First Trimester Trophoblast Apoptosis through an Inflammatory Mechanism. American Journal of Reproductive Immunology 2010, 64:27-37.

32. Tayade C, Black GP, Fang Y, Croy BA: Differential Gene Expression in Endometrium, Endometrial Lymphocytes, and Trophoblasts during Successful and Abortive Embryo Implantation. The Journal of Immunology 2006, 176:148-156.

33. Stewart-Akers AM, Krasnow JS, Brekosky J, DeLoia JA: Endometrial leukocytes are altered numerically and functionally in women with implantation defects. Am J Reprod Immunol 1998, 39:1-11.

34. Piccinni MP, Romagnani S: Regulation of fetal allograft survival by a hormone-controlled Th1-and Th2-type cytokines. Immunol Res 1996 15:141-150.

35. Wilczynski JR: Th1/Th2 cytokines balance-yin and yang of reproductive immunology. Eur J Obstet Gynecol Reprod Biol 2005, 122:136-143.

36. Irving JA, Lala PK: Functional role of cell surface integrins on human trophoblast cell migration: regulation by TGF-beta, IGF-II, and IGFBP-1. Exp Cell Res 1995, 217:419-427.

37. Klentzeris LD: The role of endometrium in implantation. Hum Reprod 1997, 12:170-175.

38. Piccinni MP, Maggi E, Romagnani S: Role of hormone-controlled T-cell cytokines in the maintenance of pregnancy. Biochem Soc Trans 2000, 28:212-215.

39. Piccinni MP, Scaletti C, Maggi E, Romagnani S: Role of hormone-controlled Th1-and Th2-type cytokines in successful pregnancy. J Neuroimmunol 2000, 109:30-33.

40. Jauniaux E, Gulbis B, Schandene L, Collette J, Hustin J: Distribution of interleukin- 6 in maternal and embryonic tissues during the first trimester. Mol Hum Reprod 1996, 2:239-243.

41. Dubinsky V, Poehlmann TG, Suman P, Gentile T, Markert UR, Gutierrez G: Role of regulatory and angiogenic cytokines in invasion of trophoblastic cells. Am J Reprod Immunol 2010, 63:193-199.

42. Husslein H, Haider S, Meinhardt G, Prast J, Sonderegger S, Knöfler M: Expression, Regulation and Functional Characterization of Matrix Metalloproteinase-3 of Human Trophoblast. Placenta 2009, 30:284-291.

43. Zhou WH, Du MR, Dong L, Yu J, Li DJ: Chemokine CXCL12 promotes the cross-talk between trophoblasts and decidual stromal cells in human first-trimester pregnancy. Hum Reprod 2008, 23:2669-2679.

44. Jaleel MA, Tsai AC, Sarkar S, Freedman PV, Rubin LP: Stromal cell-derived factor-1 (SDF-1) signalling regulates human placental trophoblast cell survival. Mol Hum Reprod 2004, 10:901-909.

45. Karmakar S, Dhar R, Das C: Inhibition of Cytotrophoblastic (JEG-3) Cell Invasion by Interleukin 12 Involves an Interferon $\gamma$-mediated Pathway. Journal of Biological Chemistry 2004, 279:55297-55307.

46. Scott VL, Burgess SC, Shack LA, Lockett NN, Coats KS: Expression of CD134 and CXCR4 mRNA in term placentas from FIV-infected and control cats. Vet Immunol Immunopathol 2008, 123:90-96.

47. Joshi A, Garg H, Tompkins MB, Tompkins WA: Preferential feline immunodeficiency virus (FIV) infection of CD4+ CD25+ T-regulatory cells correlates both with surface expression of CXCR4 and activation of FIV long terminal repeat binding cellular transcriptional factors. J Virol 2005, 79:4965-4976.

48. Joshi A, Vahlenkamp TW, Garg H, Tompkins WA, Tompkins MB: Preferential replication of FIV in activated CD4(+)CD25(+)T cells independent of cellular proliferation. Virology 2004, 321:307-322.

49. Chan S, Murray PG, Franklyn JA, McCabe CJ, Kilby MD: The use of laser capture microdissection (LCM) and quantitative polymerase chain reaction to define thyroid hormone receptor expression in human 'term' placenta. Placenta 2004, 25:758-762.

doi:10.1186/1743-422X-8-336

Cite this article as: Scott et al.: Immunomodulator expression in trophoblasts from the feline immunodeficiency virus (FIV)-infected cat Virology Journal 2011 8:336.

\section{Submit your next manuscript to BioMed Central and take full advantage of:}

- Convenient online submission

- Thorough peer review

- No space constraints or color figure charges

- Immediate publication on acceptance

- Inclusion in PubMed, CAS, Scopus and Google Scholar

- Research which is freely available for redistribution

Submit your manuscript at www.biomedcentral.com/submit 